\title{
GROWTH PERFORMANCE, HEMATOLOGICAL DISORDER AND BACTERIAL CHALLENGE ON NILE TILAPIA (OREOCHROMIS NILOTICUS) USING MORINGA OLEIFERA PLANT LEAF AS FEED SUPPLEMENT
}

\author{
Md. Baki Billah*, Md. Enamul Haque, Shilpi Sarkar, Md. Mozammel Hossain ${ }^{1}$ \\ and Shuvra Kanti Dey² \\ Department of Zoology, Jahangirnagar University, Savar, Dhaka-1342, \\ Bangladesh
}

\begin{abstract}
Tilapia (Oreochromis niloticus) has been gaining ground in cultivation and sale in Bangladesh but due to price hike of fish feed the culture of this fish faced many challenges. In the present study, the optimal level of dietary moringa (Moringa oleifera) leaf powder was used as feed supplement to determine the growth performances, some selective blood parameters and bacterial load in Nile tilapia, Oreochromis niloticus. Commercial feed with processed moringa leaf at $0 \mathrm{~g} / \mathrm{kg}, 100 \mathrm{~g} / \mathrm{kg}$ and $200 \mathrm{~g} / \mathrm{kg}$ diet was used. The diet containing $100 \mathrm{~g}$ moringa leaf/kg diet resulted in increased weight gain, average daily gain, specific growth rate, condition factor and survival rate. A significant $(\mathrm{p}<0.05)$ reduction in $R B C$ and WBC were observed as increasing amount of processed moringa leaf was added in the diets but no significant differences were observed among the three different rearing conditions. In most of the cases, the diet containing $100 \mathrm{~g}$ moringa leaf powder $/ \mathrm{kg}$ diet displayed lower amount of bacterial count but no significant improvement was found in bacterial load among the different treatment conditions. The results suggest that addition of moringa leave powder with commercial diet at $100 \mathrm{~g} / \mathrm{kg}$ diet may be better for growth, survival, immune response and microbial challenge of Nile tilapia.
\end{abstract}

Key words: Moringa oleifera, Oreochromis niloticus, life parameters, bacterial load

\section{INTRODUCTION}

Nile tilapia, Oreochromis niloticus is a popular and common aquaculture fish in Bangladesh. Within a very short time O. niloticus assume bigger size and grows very fast (Getachew Teferra 1987). They are omnivorous and mainly rely on algae, aquatic plants, small invertebrates, detritus and associated bacterial films for their nutritional pursuit (Getachew Teferra 1987; Diana et al. 1991). The successful culture of tilapia $O$. niloticus might be affected by incidences of

*Author for correspondence: <bakibillah29@gmail.com>. ${ }^{1}$ Department of Biochemistry and Molecular Biology, Jahangirnagar University, Savar, Dhaka-1342, Bangladesh, ${ }^{2}$ Department of Microbiology, Jahangirnagar University, Savar, Dhaka-1342, Bangladesh

C2020 Zoological Society of Bangladesh. DOI: https://doi.org/10.3329/bjz.v48i1.47884 
mass mortality due to the prevalence of bacterial diseases (Mortuza and AlMisned 2013; Mandal et al. 2009). The common bacterial diseases observed in O. niloticus are caused by Streptococcus spp., Pseudomonas fluorescens (Miyazaki et al. 1984), Aeromonas hydrophila (Leung et al. 1994), Edwardsiella spp. (Kaige et al. 1986) and Vibrio vulnificus (Sakata and Hattori 1988). Fin fish and shell fish aquaculture is faced with serious vibriosis problem (Rasheed 1989), and many have been putting efforts adopting different novel approaches to overcome this disease problem in fisheries sector (Chevassus and Dorson 1990).

The use of antibiotics is a common practice in fish culture but antibiotic therapy has also been criticized due to the potential for increased microbial resistance and the possibility of residual accumulation in the fish tissues (Chevassus and Dorson 1990). The medical and pharmaceutical industries are producing new drugs and the microbes are becoming modified to change their metabolism and genetic makeup to acquire resistant against these drugs used in the treatment of common infectious diseases (Raghunath 2008; Tenover 2006).

Therefore, development of alternative and innovative drugs against the drug resistance microbes is of great interest to the scientific community. For the treatment of various infectious diseases, different kind of natural medicinal compounds may be extracted from the natural sources such as algae, plants and animals. The traditional medicinal system has been used plants as a medicinal source for the treatment of infectious diseases since long. But recently plants have been extensively explored for drug discovery and development for their medicinal properties (De Pasquale 1984; Cragg and Newman 2005). Moreover, researches on plants are in vogue globally due to their antimicrobial, anticancer, anti-inflammatory, antidiabetic, hemolytic, antioxidant, and larvicidal properties (Thilza et al. 2010).

Moringa plant is important in aquaculture for the acceptable odor of their flowers, leaves and seeds and considered as one of the most important plant protein sources for fish (Makkar and Becker 1997). The people of African countries such as Ghana, Ethiopia, Nigeria, East Africa and Malawi use Moringa leaves as their food and medicinal purposes (Olson 2002). High content of protein, minerals and vitamins are associated with moringa leaves and hence used as an ideal nutritional supplement (Fletcher 1998). Due to price hike of fish feeds, aquaculture nutrition is focused on identification and utilization of non-conventional and lower-utilized plant protein sources to replace of fish meal (Siddhuraju and Becker 2003). Moringa oleifera tree is considered as the potential sources of nutrition and could be used as ingredients in fish feed formulation (Yuangsoi and Masumoto 2012). 
Many commercial fish feed industries are in high demand due to the rapid flourish of aquaculture sector. Different feeds are utilized by different fish species. But the quality and contamination in fish feed is a grave concern. The good quality feed may increase the production, immune response and become adapted the fish with adverse environment but feed with deficit nutritional quality may provoke malnutrition leading to diseases progression and death (Mollah et al. 2009). The European Union has authorized some synthetic antioxidants as additive in fish meal. In different countries, ethoxyquin and butylated hydroxytoluene and carotenoid pigments are used as feed additives to increase the feeding efficiency, antioxidant properties, reduce microorganisms, and to decrease fish fatality (Dada et al., 2015). But due to their price hike and unavailability, farmers in Bangladesh mainly rely on traditional practices. Several studies have been carried out on fish growth and feed utilization using plant materials including moringa leaf (Afuang et al. 2003; Puycha et al. 2017).

Tilapia cultivation is gaining peak in Bangladesh because of its high nutritional value, palatable taste, and low cost in cultivation. But the existing commercial fish feed in the markets are pretty expensive. Therefore, scientists across the globe are concentrating on alternative to fish feed. As plant proteins are cheap and available, research on the utilization of plant parts as supplement of fish feed demand huge appreciation in aquaculture (Puycha et al. 2017). Therefore, the present research was aimed to examine the performance of Moringa oleifera as fish feed supplement and their effects on fish health. The objectives were to examine the effects of moringa leaf on life parameters and bacterial load of $O$. niloticus.

\section{MATERIAL AND METHODS}

Preparation of plant extracts: The Moringa oleifera leaves were collected from Jahangirnagar University campus, Savar, Dhaka, Bangladesh during February 2019. The leaves were washed thoroughly using distilled water and dried under shade followed by drying in an oven at $45^{\circ} \mathrm{C}$ for 48 hours before grinding. The dried plant materials were grinded into powder with an electrical blender.

Fish, diets and feeding protocol: Fishes were maintained and the diet was formulated as previously described by many authors (Puycha et al. 2017 and Begum et al. 2018). Briefly, prior to feeding the experimental diets, tilapia fry were kept in water filled aquarium with fish feed containing $40 \%$ of protein for 3 weeks. The fry were obtained from fish hatchery and research center of the Department of Zoology at Jahangirnagar University campus. After 3 weeks, tilapia fry were distributed into three aquariums having three replications and each group with 80 fish (average $4.12 \pm 0.03 \mathrm{~g}$ ) in an aquarium (60L capacity). Three diets were formulated using moringa leaf crush at $0 \mathrm{~g} / \mathrm{kg}$ diet, $100 \mathrm{~g} / \mathrm{kg}$ 
diet and $200 \mathrm{~g} / \mathrm{kg}$ diet (Puycha et al. 2017). The diets were applied to the aquarium named as T1, T2 and T3. T1 was regarded as control: commercial feed $+0 \mathrm{~g}$ moringa leaf $/ \mathrm{kg}$ diet, treatment 2 (T2): commercial feed $+100 \mathrm{~g}$ moringa leaf $/ \mathrm{kg}$ diet and treatment 3 (T3): commercial feed $+200 \mathrm{~g}$ moringa leaf $/ \mathrm{kg}$ diet. The fish were hand fed twice a day ( 9 am and $4 \mathrm{pm}$ ) for 60 days. Sampling was done each 7 days interval. In order to get the accurate weight, the fish were not given food for last $24 \mathrm{~h}$. Water samples of each treatment were tested for bacterial load at 20 days interval (Begum et al. 2018) and the entire process for assessment of bacterial load was followed by Cappuucino and Sherman (1996). The unconsumed excess food that remains in the aquarium was removed after each feeding. Everyday fecal pellets and other unwanted materials were also siphoned from each aquarium.

Water quality parameters: The physico-chemical parameters of water i.e., temperature, $\mathrm{pH}$, and dissolved oxygen (DO) were investigated with the help of aqua mate water testing kit (HACH, USA). The microbial work was conducted at the Department of Microbiology, Jahangirnagar University and all the other analysis were done in the Department of Zoology, Jahangirnagar University, Savar, Dhaka, Bangladesh.

Body parameters: Body measurements were calculated using the formula used by Begum et al. (2018).

1) Weight gain $=$ Average final weight - average initial weight.

2) Average Daily Gain (ADG, g/day) was calculated by subtracting the mean initial weight from mean final weight and dividing the ratio by time interval.

3) Specific Growth Rate $(\mathrm{SGR})=\left(\ln \left(\mathrm{W}_{\mathrm{f}}\right)-\ln \left(\mathrm{W}_{\mathrm{i}}\right)\right) \times 100 / \mathrm{t}$

$\ln \left(\mathrm{W}_{\mathrm{f}}\right)=$ the natural logarithm of the final weight, $\ln \left(\mathrm{W}_{\mathrm{i}}\right)=$ the natural logarithm of the initial weight, $\mathrm{t}=$ time (days) among $\ln \left(\mathrm{W}_{\mathrm{f}}\right)$ and $\ln \left(\mathrm{W}_{\mathrm{i}}\right)$

4) Feed Conversion Ratio (FCR) was measured by dividing the amount of consumed feed with the respective weight gain.

5) Condition factor, $\mathrm{K}=\mathrm{W} / \mathrm{L} 3 \times 100$ where, $\mathrm{K}=$ Condition factor, $\mathrm{W}=$ Body weight in grams and $\mathrm{L}=$ Body length in $\mathrm{cm}$.

6) The survival rate (\%) was estimated by dividing the number of fry with total number of stock and multiplying the ratio with 100 .

Determination of hematological parameters: At 60 days of exposure period, blood samples were collected from the caudal vein of 20 fishes randomly selected from each treatment. The blood samples were taken in falcon tube with EDTA for subsequent analysis. Selective hematological parameters (RBC, WBC and hemoglobin content) and morphological observations of RBC were examined according to Verma (1994). 
Determination of bacterial load: Different selective media were used for the identification and counts of different bacterial strains according to Abbas (2014). Colony count was performed by plating serial ten-fold dilutions on nutrient agar, MacConkey agar, SS (Salmonella Shigella) agar and TCBS (Thiosulphate Citrate Bile Salt Sucrose) agar by the spread plate method. Streak plate method was used to get the pure culture of the isolates. The plates were incubated at $37^{\circ} \mathrm{C}$ and were observed after $24 \mathrm{~h}$. The colonies of E. coli, Salmonella spp. Shigella spp. and Vibrio spp. appeared characteristics color after incubation. Following incubation, number of colony was counted in cfu/g of sampled fish as well as isolated and identified according to the colony morphology.

Statistical analysis: The body parameters and the relationship among them were analyzed by one-way analysis of variance (ANOVA). The results were considered significant at $0.05 \%$ level and the homogeneity of the data was maintained by means of Duncan's Multiple Range Test (DMRT) using SPSS 17.0 program.

\section{RESULTS AND DISCUSSION}

Body parameters, selective hematological parameters and bacterial load of $O$. niloticus were investigated at different time periods. In addition, the water quality parameters of the treatment conditions were examined.

Water quality parameters for culturing $O$. niloticus: For rearing the fry of $O$. niloticus, the water quality parameters of the three treatments routinely investigated throughout the study were summarized in Table 1.

Table1. Physico-chemical properties of water in three treatment conditions during the exposure period

\begin{tabular}{|c|c|c|c|c|}
\hline Parameters & $\begin{array}{c}\text { Commercial feed+ } 0 \\
\mathrm{~g} \text { moringa leaf / kg } \\
\text { diet (T1) }\end{array}$ & $\begin{array}{l}\text { Commercial feed } \\
+100 \mathrm{~g} \text { moringa } \\
\text { leaf / kg diet (T2) }\end{array}$ & $\begin{array}{l}\text { Commercial feed } \\
+200 \mathrm{~g} \text { moringa } \\
\text { leaf / kg diet (T3) }\end{array}$ & $\begin{array}{l}\text { Level of } \\
\text { significance }\end{array}$ \\
\hline Temperature $\left({ }^{\circ} \mathrm{C}\right)$ & $29 \pm 0.14$ & $28 \pm 0.25$ & $29 \pm 0.49$ & NS \\
\hline $\mathrm{pH}$ & $7.8 \pm 0.18$ & $7.4 \pm 0.22$ & $7.7 \pm 0.33$ & NS \\
\hline $\mathrm{DO}(\mathrm{mg} / 1)$ & $5.3 \pm 0.26$ & $5.5 \pm 0.11$ & $5.1 \pm 0.43$ & NS \\
\hline
\end{tabular}

NS indicates non-significant at $0.05 \%$ level.

Water quality parameters varied in different treatments based on the different types of diets used. But the fluctuations in different physico-chemical parameters did not differ significantly and did not show any negative impacts on fish. Temperature may produce shock and cause mortality in fish. Most tropical fish, for example tilapia, die at temperatures less than $10^{\circ} \mathrm{C}$. Similarly, the amount of dissolved oxygen (DO) is critical for the survival of aquatic organisms 
(Effendi et al., 2015). According to WHO (2004), the optimum range of $\mathrm{pH}$ for inland surface water was between 6.5 and 8.5. In this experiment, the water temperature ranged among $28-29^{\circ} \mathrm{C}$, DO ranged among $5.1-5.5 \mathrm{mg} / 1$ and $\mathrm{pH}$ ranged among 7.4-7.8. No significant differences $(p>0.05)$ in mean values among the treatments were recorded. The water quality parameters recorded in this study were in agreement with the criteria for standard aquaculture practices (DoF 2010).

\section{Growth performance of 0 . niloticus}

Weight gain: On 40th day the highest weight gain was found in T2 $14.63 \pm$ $1.05 \mathrm{~g})$ fed with commercial feed with $100 \mathrm{~g}$ moringa leaf $/ \mathrm{kg}$ diet and the lowest was in T1 $(4.04 \pm 1.11 \mathrm{~g})$ where only commercial diet was given (Fig. 1A). On $60^{\text {th }}$ day, the maximum weight $(6.52 \pm 1.22)$ was recorded where fish was given commercial diet with $100 \mathrm{~g}$ moringa leaf/kg diet than commercial feed containing Og moringa leaf $/ \mathrm{kg}$ diet and $200 \mathrm{~g}$ moringa leaf $/ \mathrm{kg}$ diet. No significant $(\mathrm{p}>0.05)$ differences were observed among the three different rearing conditions. The similar observations were observed in Bocourti's catfish (Pangasius bocourti) supplemented with 100g moringa leaf/kg diet (Puycha et al. 2017).

Average daily gain, $A D G$ (g/day): The highest mean ADG was found in T2 $(1.74 \pm 0.89 \mathrm{~g} /$ day $)$ and the lowest in T3 $(1.64 \pm 0.93 \mathrm{~g} /$ day $)$. At the end of the exposure period (60 days), T2 exhibited better performance in ADG (1.74 \pm 0.76 $\mathrm{g} /$ day) compared to $\mathrm{T} 1$ and T3. Insignificant ( $>0.05)$ differences were observed among the three different rearing conditions (Fig. 1B).

Specific growth rate, SGR (\%): The highest mean SGR was found in T2 $(0.723 \pm 0.052)$ and the lowest in $\mathrm{T} 1(0.663 \pm 0.003)$. At the end of the exposure period (60 days), similarly T2 demonstrated better results $(0.723 \pm 0.052)$ compared to T1 and T3. Significant $(p>0.05)$ differences were not observed among the three different rearing conditions (Fig. 1C).

Doctolero and Bartolome (2019) found significant improvement in growth and survival rate of Nile tilapia using different level of $M$. oleifera treatment as feed additives. They observed better growth in treatment with $20 \% \mathrm{M}$. oleifera incorporated in fish diets. Richter et al. (2003) evaluated the necessity of moringa leaf as source of protein for $O$. niloticus). In their study they found that moringa leaf meal at the level of $10 \%$ and $20 \%$ exhibited the higher SGR $(2.7 \%$ and $2.4 \%$ respectively). Another work on cinnamon bark powder on Heteropneustes fossilis highlighted the greater SGR $(0.73 \pm 0.25 \%)$ which were in agreement with this present research.

Condition factor (\%): The average highest condition factor was recorded in T2 $(0.56 \pm 0.13 \%)$ compared to T3 and T1. On $60^{\text {th }}$ day, T2 showed the greater condition factor $(0.58 \pm 0.95 \%)$. But, significant $(p>0.05)$ differences were not 
observed among the three different rearing conditions (Fig. 1D). The condition factor varies from species to species. A study on the effects of cinnamon powder on Nile tilapia found relatively higher condition factor ranged from $0.5-1.5 \%$ (Ahmad et al. (2011). But another study demonstrated condition factor ( 0.66\%) in Singhi exposed to different level of cinnamon extracts, similar to this present study (Begum et al. 2018).

Feed conversion ratio, FCR (\%): Fish fed with commercial feed exhibited the lowest $(4.28 \pm 0.91 \%)$ FCR while the greater values were found in fish fed with commercial feed with $100 \mathrm{~g}$ moringa leaf $/ \mathrm{kg}$ diet and commercial feed containing $200 \mathrm{~g}$ moringa leaf $/ \mathrm{kg}$ diet respectively (Fig. 1E). No significant ( $>0.05$ ) differences were observed among the three different rearing conditions.

Ozovehe et al. (2013) studied the growth performance of juvenile Clarias gariepinus fed varying levels of Moringa oleifera leaf meal diet. But no significant differences between control diet and diet with different levels of moringa powder in terms of different body parameters such as MWG, SGR and FCR. Another study by Begum et al. (2018) highlighted that addition of cinnamon at $0.5 \%$ level with commercial feed increased the FCR (3.18\%) in Heteropneustes fossilis.

Survival rate (\%): Among the 3 treatments, T1 exhibited the highest survival rate $(98 \pm 4.1 \%)$ followed by T2 $(97 \pm 6.13 \%)$ and T3 $(95 \pm 3.98 \%)$ (Fig. $1 \mathrm{~F})$. Dienye and Olumuji (2014) conducted an experiment on growth performance and hematological responses of African mud catfish Clarias gariepinus fed dietary levels of Moringa oleifera leaf meal and found the highest survival rate in fish fed with 50\% Moringa oleifera diet.

\section{Changes in selective hematological parameters}

Total Red Blood Cell (RBC) count: The amounts of total RBCs in control fishes were higher compared to the treated groups. The number of RBCs in O. niloticus fed with commercial feed $+100 \mathrm{~g}$ moringa leaf $/ \mathrm{kg}$ diet and commercial feed + $200 \mathrm{~g}$ moringa leaf $/ \mathrm{kg}$ diet decreased significantly $(\mathrm{p}<0.05)$ compared to control (commercial feed + Og moringa leaf $/ \mathrm{kg}$ diet). Fish only fed with commercial feed exhibited the highest $\left(3.72 \pm 0.91 \times 10^{6} / \mathrm{mm}^{3}\right)$ RBCs count while lower value $\left(3.67 \pm 1.11 \times 10^{6} / \mathrm{mm}^{3}\right)$ was found in fish fed with commercial feed with $200 \mathrm{~g}$ moringa leaf $/ \mathrm{kg}$ diet. After 60 days exposure period the RBCs assumed round and dilated in shape (Fig. 2D). No significant $(p>0.05)$ differences were observed among the three different rearing conditions.

Total WBC count: The number of total WBC in treatment groups i.e., T2 (commercial feed +100 moringa leaf $\mathrm{g} / \mathrm{kg}$ diet) and T3 (commercial feed $+200 \mathrm{~g}$ moringa leaf $/ \mathrm{kg}$ diet) were significantly $(\mathrm{p}<0.05)$ lower compared to control T1 (commercial feed $+0 \mathrm{~g}$ moringa leaf $/ \mathrm{kg}$ diet). The average lowest WBC count was 

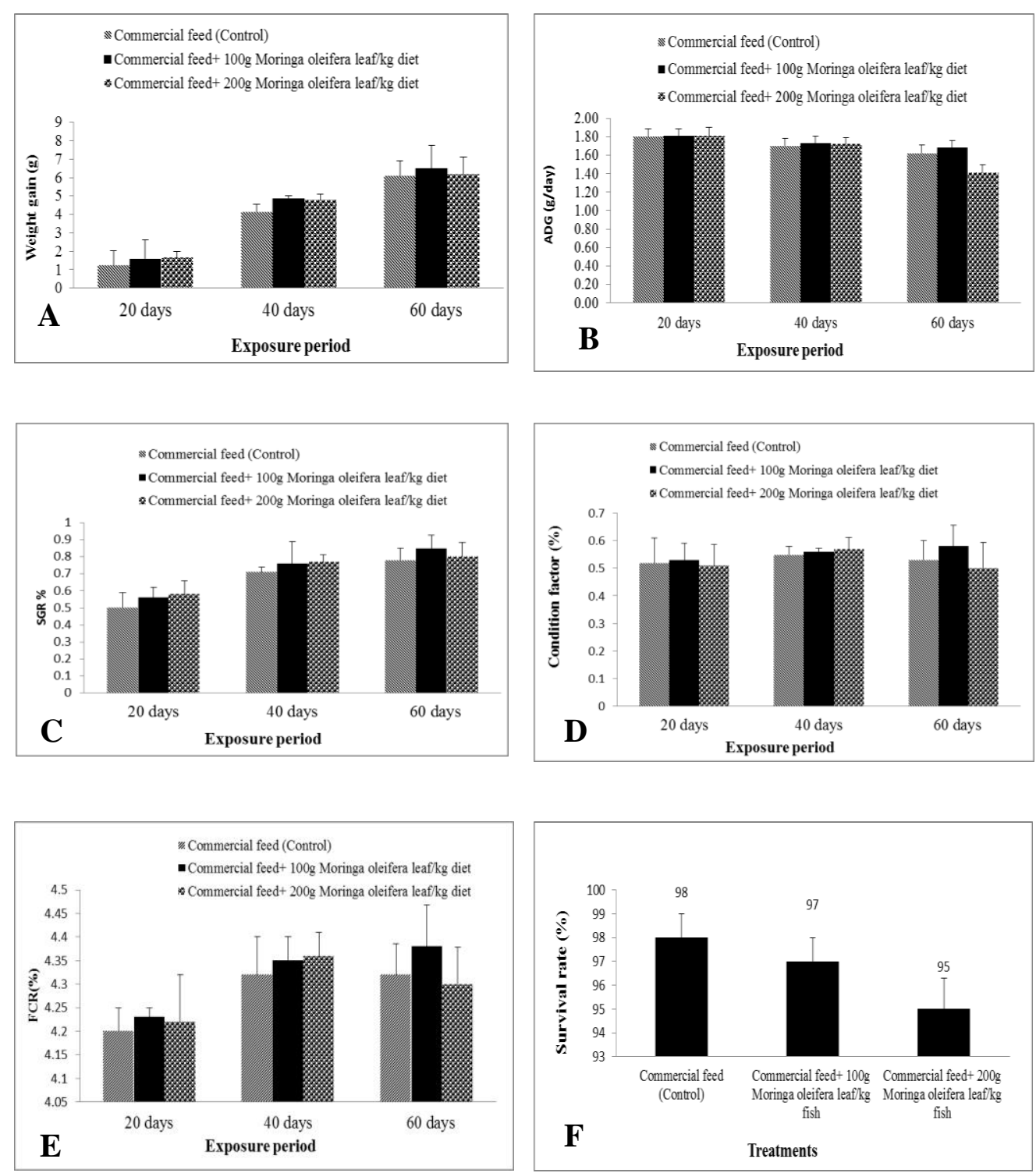

Fig.1. Growth parameters and survival of $O$. niloticus fed with commercial feed at different inclusion of Moringa oleifera leaf powder for 60 days rearing period: (A) weight gain (g) (B) average daily gain (g/day) (C) specific growth rate (\%) (D) Condition factor (\%) (E) Feed conversion ratio (\%) (F) Survival rate $(\%)$. No letter on bars represents a no-significant condition (ANOVA, $p>0.05$ ).

recorded in T3 $\left(30.5 \pm 5.17 \times 10^{3} / \mathrm{mm}^{3}\right)$ followed by T1 and T2 (Fig.2). No significant $(p>0.05)$ differences were observed among the three different rearing conditions. 
Hemoglobin content $(\mathrm{Hb})$ : The $\mathrm{Hb}$ content in $\mathrm{T} 2$ were greater $(9.9 \pm 2.12 \%)$ and exhibited the decreasing pattern in T1 $(9.7 \pm 1.12 \%)$ and $\mathrm{T} 3 \quad(9.1 \pm 3.05 \%)$ respectively. After 60 days of exposure, the highest $\mathrm{Hb}$ content was recorded in T2 $(9.8 \pm 4.22 \%)$ and the lowest in T3 (8.5 \pm 1.07$)$ (Fig.2). The different treatment conditions did not show any significant $(p>0.05)$ difference in terms of Hemoglobin content

Ahmed et al. (2014) experimented the effect of $M$. oleifera leaf on growth performance and immune status of Nile tilapia diets and observed higher concentration of $\mathrm{RBC}, \mathrm{WBC}$ and $\mathrm{Hb}$ in treatment 2 (T2) where $10 \%$ Moringa oleifera leaf was incorporated into the diets. Another study conducted by Ayotunde et al.
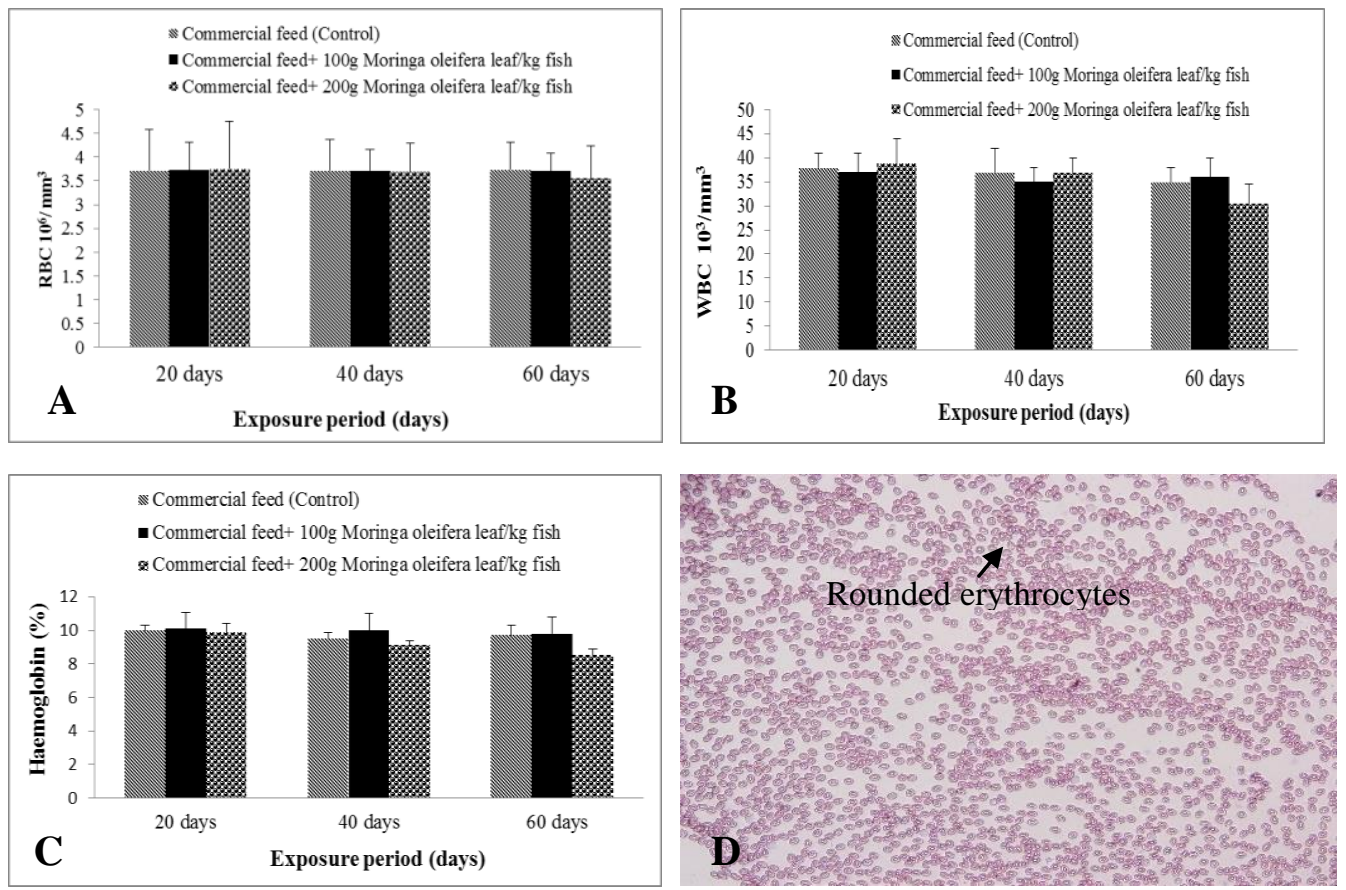

Fig. 2: Selective hematological parameters of $O$. niloticus fed with commercial feed at different inclusion of Moringa oleifera leaf powder for 60 days rearing period: (A) total count of RBC (B) total count of WBC (C) total hemoglobin contents and (D) changes in erythrocytes of Oreochromis niloticus. Bars (Mean $\pm \mathrm{SD}$ ) with no superscripts were not significant within group (ANOVA, $\mathrm{p}>0.05$ ).

(2004) examined the toxic effect of aqueous extracts of Moringa oleifera on some blood parameters of $O$. niloticus fingerlings and adults. They found increased level of $\mathrm{RBC}, \mathrm{WBC}$ and $\mathrm{Hb}$ contents in case of fingerlings whereas increased $\mathrm{RBC}, \mathrm{Hb}$ and reduction in the $\mathrm{WBC}$ values were observed in case of adults. 
Abbas and El-Badawi (2014) observed the effect of acute and chronic exposure of $M$. oleifera seeds extract on some hematological parameters of O. niloticus. At the end of the experiment they found that, $\mathrm{RBC}$ and $\mathrm{Hb}$ contents were significantly decreased whereas WBC contents were increased in comparison with control groups. On the other hand, Kavitha et al. (2012) also studied the toxicity of Moringa oleifera seed extract on some hematological and biochemical profiles in a freshwater fish, Cyprinus carpio and found that during acute treatment $(96 \mathrm{~h})$, hematological variables like red blood cell count (RBC), hemoglobin $(\mathrm{Hb})$ as well as mean corpuscular hemoglobin concentration (MCHC) were significantly $(\mathrm{p}<0.05)$ decreased in fish exposed to seed extracts. All the above findings from different authors are more or less identical to our study.

\section{Bacterial flora associated with water and fish samples}

Bacterial counts of water samples: Moringa leaf powders at different levels were added to fish in water. The total bacterial count, total Salmonella-Shigella, total E. coli., and total Vibrio counts at different conditions were represented in Table 2 .

On $20^{\text {th }}$ day, the maximum bacterial diversity was found $1.8 \pm 0.25 \times 10^{5}$ $\mathrm{cfu} / \mathrm{g}$ in $\mathrm{T} 1$ and the lowest $1.7 \pm 0.15 \times 10^{3} \mathrm{cfu} / \mathrm{g}$ in $\mathrm{T} 2$. On $40^{\text {th }}$ day, the highest bacterial count was $4.0 \pm 0.20 \times 10^{5} \mathrm{cfu} / \mathrm{g}$ in $\mathrm{T} 1$ and on $60^{\text {th }}$ day, the highest value $1.7 \pm 0.15 \times 10^{5}$ was found further in $\mathrm{T} 1$. A significant difference $(\mathrm{p}<0.05)$ was noticed among T1, T2 and T3 in different time periods. Treatment 2 (Commercial feed $+100 \mathrm{~g}$ moringa leaf powder $/ \mathrm{kg}$ diet) on $20^{\text {th }}$ days and $60^{\text {th }}$ day delivered the best result $1.7 \pm 0.15 \times 10^{3} \mathrm{cfu} / \mathrm{g}$ and $2.7 \pm 0.30 \times 10^{3} \mathrm{cfu} / \mathrm{g}$ for total bacterial counts of water samples. The highest Salmonella-Shigella count was $8.1 \pm 0.45 \times 10^{3} \mathrm{cfu} / \mathrm{g}$ in $\mathrm{T} 1$ on $40^{\text {th }}$ day and the lowest count was found $5.1 \pm 0.45$ $\times 10^{2} \mathrm{cfu} / \mathrm{g}$ in T2 on $20^{\text {th }}$ day. On $20^{\text {th }}$ day, the highest $E$. coli count, $7.4 \pm 0.65 \times$ $10^{4} \mathrm{cfu} / \mathrm{g}$ was observed in T3 and the lowest $1.0 \pm 0.10 \times 10^{2} \mathrm{cfu} / \mathrm{g}$ in T1. However, on $40^{\text {th }}$ day and $60^{\text {th }}$ day, the highest $E$. coli counts were recorded in T1 that were $1.9 \pm 0.10 \times 10^{2} \mathrm{cfu} / \mathrm{g}$ and $5.5 \pm 0.55 \times 10^{3} \mathrm{cfu} / \mathrm{g}$ respectively. On $20^{\text {th }}$ day and $40^{\text {th }}$ day, the highest Vibrio counts were $2.9 \pm 0.35 \times 10^{2} \mathrm{cfu} / \mathrm{g}$ and $1.7 \pm 0.20 \times 10^{3} \mathrm{cfu} / \mathrm{g}$ in T3 and T1 respectively. But on the $60^{\text {th }}$ day, no Vibrio count was observed in any treatment. From the above findings it was evident that the antibacterial activities of moringa leaf extracts remain persistent for long as reflected from the lowest bacterial load of T2 and T3, even the Vibrio abundance become zero at the end of exposure period $\left(60^{\text {th }}\right.$ day). But no significant $(\mathrm{p}<0.05)$ antibacterial incidence of moringa extracts were found in different exposure conditions compare to control. Brilhante et al. (2017) conducted a research on the multiple uses of Moringa oleifera and exhibited 
inhibitory activities of Moringa oleifera in case of various gram positive and gram negative bacteria. Another investigation was conducted by Begum et al. (2018) on Heteropneustes fossilis, where they observed growth performances and bacterial load of this fish and water using cinnamon as feed supplement. In most of the cases, their results showed the antimicrobial activity of cinnamon with supplementary feed which commensurate with the present findings. They also observed the effectiveness of antimicrobial activity after a certain time period.

Table 2. Bacterial count (Mean \pm SD) from water samples of different treatments during 60 days exposure

\begin{tabular}{|c|c|c|c|c|}
\hline $\begin{array}{l}\text { Bacterial } \\
\text { density (cfu/g) }\end{array}$ & Treatments & & Rearing periods & \\
\hline \multirow{4}{*}{$\begin{array}{l}\text { Total bacterial } \\
\text { count }\end{array}$} & & 20 days & 40 days & 60 days \\
\hline & Commercial fish feed & $1.8 \pm 0.25 \times 10^{5}$ & $4.0 \pm 0.20 \times 10^{5}$ & $1.7 \pm 0.15 \times 10^{5}$ \\
\hline & $\begin{array}{l}\text { Commercial feed }+100 \mathrm{~g} \text { moringa } \\
\text { leaf powder } / \mathrm{kg} \text { diet }\end{array}$ & & $1.1 \pm 0.25 \times 10^{4}$ & $2.7 \pm 0.30 \times 10^{3}$ \\
\hline & $\begin{array}{l}\text { Commercial feed+ } 200 \mathrm{~g} \text { moringa } \\
\text { leaf powder } / \mathrm{kg} \text { diet }\end{array}$ & $1.2 \pm 0.35 \times 10^{5}$ & $5.6 \pm 0.30 \times 10^{3}$ & $2.7 \pm 0.35 \times 10^{4}$ \\
\hline \multirow{3}{*}{$\begin{array}{l}\text { Total Salmonella } \\
\text { Shigella count }\end{array}$} & Commercial fish feed & $7.1 \pm 0.55 \times 10^{3}$ & $8.1 \pm 0.45 \times 10^{3}$ & $4.1 \pm 0.40 \times 10^{3}$ \\
\hline & $\begin{array}{l}\text { Commercial feed }+100 \mathrm{~g} \text { moringa } \\
\text { leaf powder } / \mathrm{kg} \text { diet }\end{array}$ & $5.1 \pm 0.45 \times 10^{2}$ & $7.0 \pm 0.50 \times 10^{2}$ & $7.6 \pm 0.15 \times 10^{2}$ \\
\hline & $\begin{array}{l}\text { Commercial feed }+200 \mathrm{~g} \text { moringa } \\
\text { leaf powder } / \mathrm{kg} \text { diet }\end{array}$ & $4.1 \pm 0.30 \times 10^{3}$ & $5.3 \pm 0.65 \times 10^{2}$ & $4.2 \pm 0.30 \times 10^{3}$ \\
\hline \multirow{3}{*}{$\begin{array}{l}\text { Total E. coli } \\
\text { count }\end{array}$} & Commercial fish feed & $1.0 \pm 0.10 \times 10^{2}$ & $1.9 \pm 0.10 \times 10^{2}$ & $5.5 \pm 0.55 \times 10^{3}$ \\
\hline & $\begin{array}{l}\text { Commercial feed+ } 100 \mathrm{~g} \text { moringa } \\
\text { leaf powder } / \mathrm{kg} \text { diet }\end{array}$ & $1.7 \pm 0.20 \times 10^{3}$ & \multirow{2}{*}{$\begin{array}{l}1.5 \pm 0.10 \times 10^{2} \\
1.5 \pm 0.10 \times 10^{2}\end{array}$} & $1.6 \pm 0.15 \times 10^{3}$ \\
\hline & $\begin{array}{l}\text { Commercial feed }+200 \mathrm{~g} \text { moringa } \\
\text { leaf powder } / \mathrm{kg} \text { diet }\end{array}$ & $7.4 \pm 0.65 \times 10^{4}$ & & $1.9 \pm 0.10 \times 10^{2}$ \\
\hline \multirow{3}{*}{$\begin{array}{l}\text { Total Vibrio } \\
\text { count }\end{array}$} & \multirow{2}{*}{$\begin{array}{l}\text { Commercial fish feed } \\
\text { Commercial feed }+100 \mathrm{~g} \text { moringa } \\
\text { leaf powder } / \mathrm{kg} \text { diet }\end{array}$} & $1.9 \pm 0.10 \times 10^{3}$ & $1.7 \pm 0.20 \times 10^{3}$ & 0 \\
\hline & & $1.9 \pm 0.20 \times 10^{2}$ & $1.4 \pm 0.10 \times 10^{2}$ & 0 \\
\hline & $\begin{array}{l}\text { Commercial feed }+200 \mathrm{~g} \text { moringa } \\
\text { leaf powder } / \mathrm{kg} \text { diet }\end{array}$ & $2.9 \pm 0.35 \times 10^{3}$ & $1.2 \pm 0.30 \times 10^{3}$ & 0 \\
\hline
\end{tabular}

Bacterial counts of fish samples: Bacterial loads on fish samples are presented in Table 3. The highest total bacterial count of fish samples were observed in T1 $\left(5.8 \pm 0.70 \times 10^{5} \mathrm{cfu} / \mathrm{g}\right)$, whereas the lowest count was estimated in T3 (1.6 \pm $\left.0.15 \times 10^{3} \mathrm{cfu} / \mathrm{g}\right)$. Maximum total Salmonella-Shigella was counted from T3 (1.8 \pm $\left.0.20 \times 10^{3} \mathrm{cfu} / \mathrm{g}\right)$ and minimum total Salmonella-Shigella from T1 $(1.8 \pm 0.10 \times$ $\left.10^{2} \mathrm{cfu} / \mathrm{g}\right)$, where fish were fed with only commercial feed. 
Accordingly, the highest total E. coli from fish sample was observed in T2 and the lowest count in T1. No vibrio was observed in any fish sample. No significant ( $p>0.05)$ changes were found in specific count of E. coli, Salmonella- Shigella, Vibrio but changes were significant in case of total count.

Jadhav and Anal (2018) conducted a study on biochemical, microbial and sensory properties of Oreochromis niloticus treated with Moringa oleifera leaves powder and they found delayed bacterial growths by increasing Moringa oleifera powder concentration. Another experiment directed by Begum et al. (2018) found the lowest total bacterial count in catfish samples fed with commercial feed only and the highest count were observed in commercial feed $+1 \%$ cinnamon treatment. But they did not find any Vibrio in fish samples.

Table 3. Bacterial load (Mean \pm SD) in tilapia exposed to different treatment conditions after 60 days exposure

\begin{tabular}{lccc}
\hline $\begin{array}{c}\text { Bacterial density } \\
\text { (cfu/g) }\end{array}$ & \multicolumn{3}{c}{ Treatments } \\
\cline { 2 - 4 } & $\begin{array}{c}\text { Commercial fish } \\
\text { feed }\end{array}$ & $\begin{array}{c}\text { Commercial feed }+100 \\
\text { g moringa leaf } \\
\text { powder/kg diet }\end{array}$ & $\begin{array}{c}\text { Commercial feed }+200 g \\
\text { moringa leaf powder } / \mathrm{kg} \\
\text { diet }\end{array}$ \\
\hline $\begin{array}{l}\text { Total bacterial } \\
\text { count }\end{array}$ & $5.8 \pm 0.70 \times 10^{5}$ & $2.3 \pm 0.25 \times 10^{3}$ & $1.6 \pm 0.15 \times 10^{3}$ \\
Total Salmonella & $1.8 \pm 0.10 \times 10^{2}$ & $2.0 \pm 0.10 \times 10^{2}$ & $1.8 \pm 0.20 \times 10^{3}$ \\
$\begin{array}{l}\text { Shigella count } \\
\text { Total E. coli count }\end{array}$ & $1.8 \pm 0.10 \times 10^{2}$ & $1.8 \pm 0.20 \times 10^{3}$ & $1.7 \pm 0.15 \times 10^{3}$ \\
Total Vibrio count & 0 & 0 & 0 \\
\hline
\end{tabular}

The acceptable limit of total bacterial count and total $E$. coli count for fish and fisheries products are $5 \times 10^{5} \mathrm{cfu} / \mathrm{g}$ and $1.0 \times 10^{2} \mathrm{cfu} / \mathrm{g}$ (ICMSF 1986). In the present study, total bacterial counts were within the acceptable limit but total $E$. coli counts were slightly higher in some cases. There are a lot of pathogenic bacteria in fish. Among them Salmonella spp. and Shigella spp are the commonly studied. According to International Commission on Microbiological Specification for Foods (ICMSF, 1986), Salmonella spp is very much detrimental to fish health and the limit should be 0cfu/g, while the acceptable limit for Shigella spp is $1.0 \times 10^{2} \mathrm{cfu} / \mathrm{g}$. From this investigation, the values of those pathogenic microorganisms were found to be moderately upper than the safe limit. In the competitive global market, it is recommended to keep the frozen fishery item free from Vibrio ssp. (ICMSF (1986) to capture the attention of consumers. In order to achieve the sustainable development goal 2 (zero hunger), it is imperative to conduct more research on traditional plants containing antimicrobial properties. 


\section{CONCLUSION}

Feed enrichment with $100 \mathrm{~g}$ moringa leaf powder $/ \mathrm{kg}$ diet showed increased growth, and feeding of Nile tilapia in laboratory condition. Bacteriological study revealed the antibacterial potential of moringa leaf. This feed additive may improve the health status of Nile tilapia as the present demonstrated relatively lower bacterial supplied with moringa powder in most of the cases. Even though, moringa leaf had some adverse effects on blood parameters, from this study, it was assumed that moringa leaf could be used as supplement of fish feed for the better output of growth, survival, immune response and microbial challenge.

\section{LITERATURE CITED}

ABBAS, H. and EL-BADAWI, A. 2014. Use of hematological and biochemical parameters and histological changes to assess the toxicity of drumstick tree (Moringa oleifera) seeds extract on Tilapia (Oreochromis niloticus) fish. Egyptian J. Aqua. Biology and Fisheries 18(3): 21-40.

ABBAS, M.S. 2014. Isolation of bacteria from fish. Int. J. Adv. Res. 2(3):274-279.

AFUANG, W., SIDDHURAJU, P. and BECKER, K. 2003. Comparative nutritional evaluation of raw, methanol extracted residues and methanol extracts of moringa (Moringa oleifera Lam.) leaves on growth performance and feed utilization in Nile tilapia (Oreochromis niloticus L.). Aquaculture Research 34(13): 1147-1159.

AHMAD, M.H., EL MESAllAMY, A.M., SAMIR, F. and ZAHRAN, F. 2011. Effect of cinnamon (Cinnamomum zeylanicum) on growth performance, feed utilization, whole-body composition, and resistance to Aeromonas hydrophila in Nile tilapia. J. Appl. Aqua. 23(4): 289-298.

AHMED, H.S., ADEL, M. and ADEL, E. 2014. Incorporation of Moringa oleifera leaf in Nile tilapia Oreochromis niloticus diet and its effect on growth performance and immune status. J. Vet. Sci.

AYOTUnDe, E.O., FAGBEnRO, O.A., ADEBAYO, O.T. and AMOO, A.I. 2004. Toxicity of Aqueous Extracts of Drumstick, Moringa oleifera, Seeds to Nile tilapia, Oreochromis niloticus, Fingerlings and Adults. In Proceedings of 6th international symposium on tilapia.

BEGUM, M.K., ESHIK, M.M.E., PUNOM, N.J., ABEDIN, M.M. and RAHMAN, M.S. 2018. Growth performances and bacterial load of Heteropneustes fossilis (Bloch, 1794) using cinnamon as feed supplement. Bangladesh J. Zool. 46(2): 155-166.

BRILHANTE, R.S.N., SALES, J.A., PEREIRA, V.S., CASTElO, D.D.S.C.M., DE AGUIAR CORDEIRO, R., DE SOUZA SAMPAIO, C.M., PAIVA, M.D.A.N., DOS SANTOS, J.B.F., SIDRIM, J.J.C. and ROCHA, M.F.G. 2017. Research advances on the multiple uses of Moringa oleifera: A sustainable alternative for socially neglected population. Asian Pacific J. Trop. Med. 10(7): 621630.

CAPPUCCINO, J.G. and SHERMAN, N. D. 1996. Microbiology. A Laboratory Manual, 4th Ed. The Benjamin/Cummings Publishing Co., Inc., Menlo Park, California, pp.13- 182. 
CHEVASSUS, B. and DORSON, M. 1990.Genetics of resistance to disease in fishes. Aquaculture 85(1-4): 83-107.

CRAGG, G.M. and NEWMAN, D.J. 2005. Biodiversity: A continuing source of novel drug leads. Pure and Applied Chemistry 77(1): 7-24.

DADA, A.A. 2015. Improvement of tilapia (Oreochromis niloticus Linnaeus, 1758) growth performance fed three commercial feed additives in diets. J. Aqua. Res. Dev. 6(325): 2.

DE-PASQUALE, A. 1984.The oldest modern science. Journal of Ethnopharmacology 11(1): 1-16.

DIANA, J.S., LIN, C.K. and SCHNEEBERGER, P.J. 1991. Relationships among nutrient input, water nutrient concentrations, primary production, and yield of Oreochromis niloticus in ponds. Aquaculture 92:323-341.

DIENYE, H.E. and OLUMUJI, O.K. 2014. Growth performance and hematological responses of African mud catfish Clarias gariepinus fed dietary levels of Moringa oleifera leaf meal. Net $J$. Agri. Sci. 2(2): 79-88.

DOCTOLERO, J.S. and BARTOLOME, R.M. 2019. Utilization of horseradish (Moringa oleifera) as an alternative protein-source feed ingredient on the diet of red Nile tilapia (Oreochromis niloticus). Int. J. Fisheries and Aquatic Studies 7(5): 94-97.

DOF: Fisheries Statistical Year Book of Bangladesh, 2009-2010. Fisheries Resource Survey System, Department of Fisheries, Ministry of Fisheries and Livestock, 27:1-42.

EFFENDI, H., ROMANTO. and WARDIATNO, Y. 2015. Water quality status of Ciambulawung River, Banten Province, based on pollution index and NSF-WQI. Procedia Environmental Sciences, 24, 228-237. doi: 10.1016/j.proenv.2015.03.030.

FLETCHER, L.J. 1998. Moringa Oleifera (the kelor tree). The Australian New Crops newsletter. Issue No. 9: 1-6.

GETACHEW TEFERRA,1987. A study on herbivores fish, Oreochromis niloticus L., diet and its quality in two Ethiopian Rift Valley lakes, Awasa and Zwai. J. Fish. Biol. 30:439-449.

ICMSF (International Commission on Microbiological Specification for Foods).1986. Microorganisms in foods. Sampling for microbiological analysis: Principles and specific applications. Blackwell Scientific Publications 2(2): 197-202.

JADHAV, R. and ANAL, A.K. 2018. Experimental investigation on biochemical, microbial and sensory properties of Nile tilapia (Oreochromis niloticus) treated with moringa (Moringa oleifera) leaves powder. J. food Sci. and Tech. 55(9): 3647-3656.

KAIGE, N., MIYAZAKI, T. and KUBOTA, S. S. 1986.A histopathological study of Edwardsiellosis in tilapia-experimental infection. Fish Pathology 21: 95-99.

KAVITHA, C., RAMESH, M., KUMARAN, S.S. and LAKSHMI, S.A. 2012.Toxicity of Moringa oleifera seed extract on some hematological and biochemical profiles in a freshwater fish, Cyprinus carpio. Experimental and toxicologic pathology 64: 681-687. 
LEUNG, K. Y., YEAP, I. V., LAM, T. J. and SIN, Y. M. 1994. Serum resistance as a good indicator for virulence in Aeromonas hydrophila strains isolated from diseased fish in South East Asia. $J$. Fish Dis. 18: 511-518.

MAKKAR, H.P.S. and BECKER, K. 1997. Nutrient and anti-quality factors in different morphological parts of Moringa oleifera tree. J. Agri. Sci. 128: 311-322.

MANDAL, S.C., HASAN, M., RAHMAN, M.S., MANIK, M.H, MAHMUD, Z.H. and ISLAM, M.S. 2009.Coliform bacteria in Nile Tilapia, Oreochromis niloticus of shrimp-Gher, pond and fish market. World J. Fish and Mar. Sci. 1(3):160-6.

MIYAZAKI, T., KUBOTA, S. S. and MIYASHITA, T. 1984.A histopathological study of Pseudomonas fluorescens infection in tilapia. Fish Pathology 19: 167-172.

MOLLAH, M.F.A., MAMUM, M.S.A., SAROWAR, M.N. and ROY, A. 2009.Effect of stocking density on growth and breeding performance of brood fish and larval growth and survival of shol, Channa striatus (Bloch). J. Bangladesh Agriculture Univ. 7(2): 427-432.

MORTUZA, M.G. and AL-MISNED, F.A. 2013.Length-weight relationships, condition factor and sexratio of Nile tilapia, Oreochromis niloticus in Wadi Hanifah, Riyadh, Saudi Arabia. World J. Zool. 8(1):106-9.

OLSON, M.E. 2002. Amplified fragment length polymorphism (AFLP) analysis of genetic variation in Moringa oleifera Lam. Molecular Ecology 8(3): 463- 470.

OZOVEHE, B.N. 2013. Growth performance, hematological indices and some biochemical enzymes of juveniles Clarias gariepinus (Burchell 1822) fed varying levels of Moringa oleifera leaf meal diet. J. Aqua. Res. Dev. 4(2).

PUYCHA, K., YUANGSOI, B., CHAROENWATTANASAK, S., WONGMANEEPRATEEP, S., NIAMPHITHAK, P. and WIRIYAPATTANASUB, P. 2017. Effect of moringa (Moringa oleifera) leaf supplementation on growth performance and feed utilization of Bocourti's catfish (Pangasius bocourti). Agriculture and Natural Resources 51(4): 286-291.

RAGHUNATH, D. 2008. Emerging antibiotic resistance in bacteria with special reference to India. Journal of Biosciences 33(4): 593-603.

RASHEED, V. 1989. Disease of cultured brown-spotted grouper, Epinephelus tauvina and silvery black porgy Acanthopagrus cuvieri in Kuwait. Journal of Aquatic Animal Health 1: 102-107.

RICHTER, N., SIDDHURAJU, P. and BECKER, K. 2003. Evaluation of nutritional quality of moringa (Moringa oleifera Lam.) leaves as an alternative protein source for Nile tilapia (Oreochromis niloticus L.). Aquaculture 217(1-4): 599-611.

SAKATA, T. and HATTORI, M. 1988. Characteristics of Vibrio vulnificus isolated from diseased tilapia. Fish Pathology 23: 33-40.

SIDDHURAJU, P. and BECKER, K. 2003. Comparative nutritional evaluation of differentially processed mucuna seeds (Mucuna pruriens L.) on growth performance, feed utilization and body composition in Nile tilapia (Oreochromis niloticus L.). Aquaculture Research 34:487-500. 
TENOVER, F. C. 2006. Mechanisms of antimicrobial resistance in bacteria. The American J. Med. 119(6): S3-S10.

THILZA, I.B., SANNI, S., ZAKARI, A.I., SANNI, F.S., TALLE, M. and JOSEPH, B.M. 2010. In vitro Antimicrobial activity of water extract of Moringa oleifera leaf stalk on bacteria normally implicated in eye diseases. Academia arena 2(6): 80-82.

VERMA, P.S. 1994. A Manual of Practical Zoology Chordates. S. Chand \& Co. Ltd.,10 th edition 1994, New Delhi. Pp 395-401.

WHO, 2004. International standards for drinking water.World Health Organization, Geneva, Switzerland.

YUANGSOI, B. and MASUMOTO, T. 2012. Replacing moringa leaf (Moringa oleifera) partially by protein replacement in soybean meal of fancy carp (Cyprinus carpio). Songklanakarin J. Sci. Tec. 34(5): 479-485.

(Manuscript received on 12 February, 2020 revised on 26 May, 2020) 